\title{
Effect of Upstream Accumulated Sediments on Fayoum Type Weir Efficiency
}

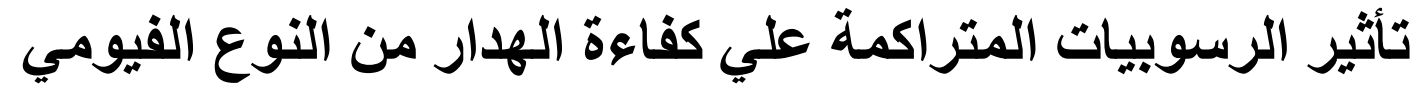

\author{
Mohammed Ibrahiem Ibrahiem Mohammed El-Gamal ${ }^{1}$, Mohamed Ahmed \\ Abdel Hady ${ }^{2}$ \\ 1\&2: Lecturers- Irrigation and Hydraulics Dept., Faculty of Engineering, \\ Mansoura University, Egypt \\ Main author E-mail: mimi_elgamal@yahoo.com \\ Co-author E-mail: Ma_abdelhady@yahoo.com
}

نتيجة التغيرات التي تحدث في معدلات التصرفات المارة في الأنهار و القنوات المائية ، تحدث تر اكمات متتالية للرسوبيات أمام الهدار ات وبمعدلات متغيرة مع الزمن. في هذا البحث تم عمل در اسة معملية لتحديد نسبة تأثير تلك فئك

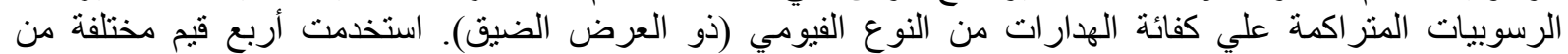

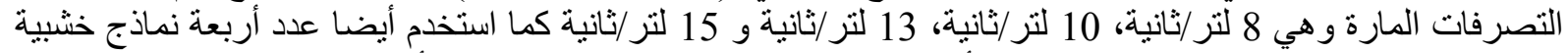

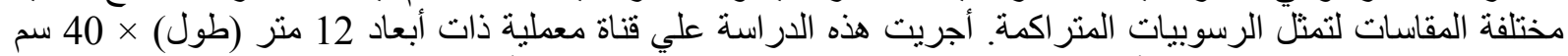

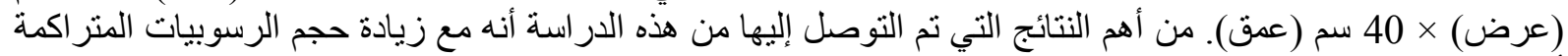

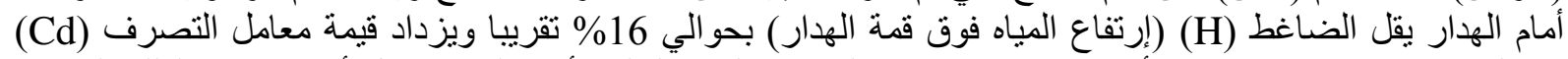

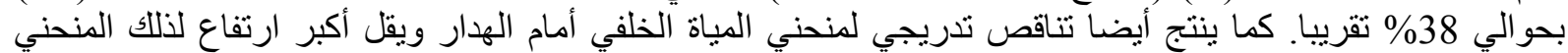
بحو الي 5,3 \%. توصي هذه الدر اسة بإز الة الرسوبيات المنر اكمة أمام الهدار ات وذلك لتحسبن كفائتها ورفع مناسيب المياة

\begin{abstract}
Under various conditions of flows in open channels with time, sediments are accumulated gradually upstream weirs. Accumulated sediments upstream weirs cause the back water curve and discharge coefficient (Cd) of weirs to change. For this reason, the effect of four different models of accumulated sediments on the discharge coefficient and the maximum height of backwater curve (Z) of Fayoum type weir (narrow crested weir) had been experimentally investigated. In this research, four values of discharges equal to 8 lit. /sec., 10 lit. /sec., 13 lit. /sec. and 15 lit. /sec. were used. From the analysis of results, compared with the case of no sediments, it was observed that with the increasing of accumulated sediments, the head over weir crest $(\mathrm{H})$ decreased by about $16 \%$ and consequently, the discharge coefficient of weir increased by about $38 \%$. The maximum height of back drawdown water curve upstream weir $(Z)$ decreased gradually with the increasing of accumulated sediments by about 5.3\%. For the aforementioned analysis, it is recommended to eliminate all of accumulated sediments upstream Fayoum type weirs for improving the performance.
\end{abstract}

\section{Key words}

Sediments, Fayoum weirs, Open channels, Experimental work.

\section{Introduction}

A weir is considered to be a barrier across any channel or river. It used to alter its flow properties. Usually, weirs used as obstructions and could be considered small compared with dams. They used for pooling water behind them and also, allowing it to flow over their tops. Weirs also are used to change the flow of natural rivers or canals for preventing them from flooding, measuring discharge, and help render rivers to be navigable.

Weirs may be used for reducing the hydraulic slope in channels and also, the head on regulators. With the increase of water demands, the capacity of the used weirs built on canals and the embankment of the canals themselves upstream of the weirs becoming insufficient to pass this 
increase of high water demands. So, the proposed solutions are modifying the old structures or replacing them by new ones.

According to the first solution, this requires a modification of the hydraulic characteristics of the weirs while the second is costly prohibitive. The modifications may be concluded in lowering weir crest or operating the existing pipes used at the bottom for emptying the canals to pass extra flow rates to downstream (Gonzalez and Chanson, 2007).

Narrow crested weirs (Fayoum type weirs) may be considered as common engineering structures used in irrigation system in Egypt, especially in Fayoum.

The name "Fayoum type weir" became known (Abdel Halim et al., 1991). Weirs, gates and pipes are usually used individually. Aggradation and degradation processes with time through rivers or canals cause sediments to accumulate upstream weirs or any other structures. Then, a combination of weirs, gates and pipes may be used to eliminate the upstream accumulated sediments.

Works concerning the flow over weirs have been mentioned by Boss et al. (1986), Hager and Schwalt (1994), Mohamed (2005), Gyğüş et al. (2006), Sargison and Percy (2009), and many others. A combination of a weir and a gate has been studied recently by many engineers and investigators. Among of them are Alhamid et al. (1997), Negm et al. (1997), Alhamid (1999), Ferro (2000), Ansar (2001) and Negm et al. (2002).

Depending on the pipe conditions and the water elevation on either side of the weir, flow is classified into three different categories; free orifice where the pipe is free pipe, submerged orifice with free overfall weir and submerged pipe and submerged weir (Samani and Mazaheri, 2009).

To find out the relationship between sediments and weirs, the CCHE2D model was used to simulate the sediment transport and the bed morphological changes in the upstream and downstream reach of Chi-Chi Weir in Choshui River, Taiwan (Yeh et al., 2010). The model has been modified to handle the bedrock erosion which was feasible and applicable to the field engineering problem. The main conclusions are; the CCHE2D model is capable of simulating sediment transport and morphological changes within the study reach with unsteady boundary conditions for the flow and sediment; the wetting and drying treatment technique of the model makes simulations with complex morphology very efficient; and the uncertainty of the data such as channel bed topography, sediment load, its composition and bed material composition may affect the prediction accuracy of the numerical model. In this research, the effect of accumulative sediments on the characteristics of Fayoum type weir would be experimentally investigated.

\section{Experimental work}

The present experiments were conducted in a rectangular flume with a mild slope of $0.40 \mathrm{~m}$ wide, $0.40 \mathrm{~m}$ deep, and $12.0 \mathrm{~m}$ long, with $2.0 \mathrm{~m}$ long Perspex sides, Fig. (1.a) and Fig. (1.b), in irrigation and hydraulics laboratory of the faculty of engineering, El-Mansoura University. 


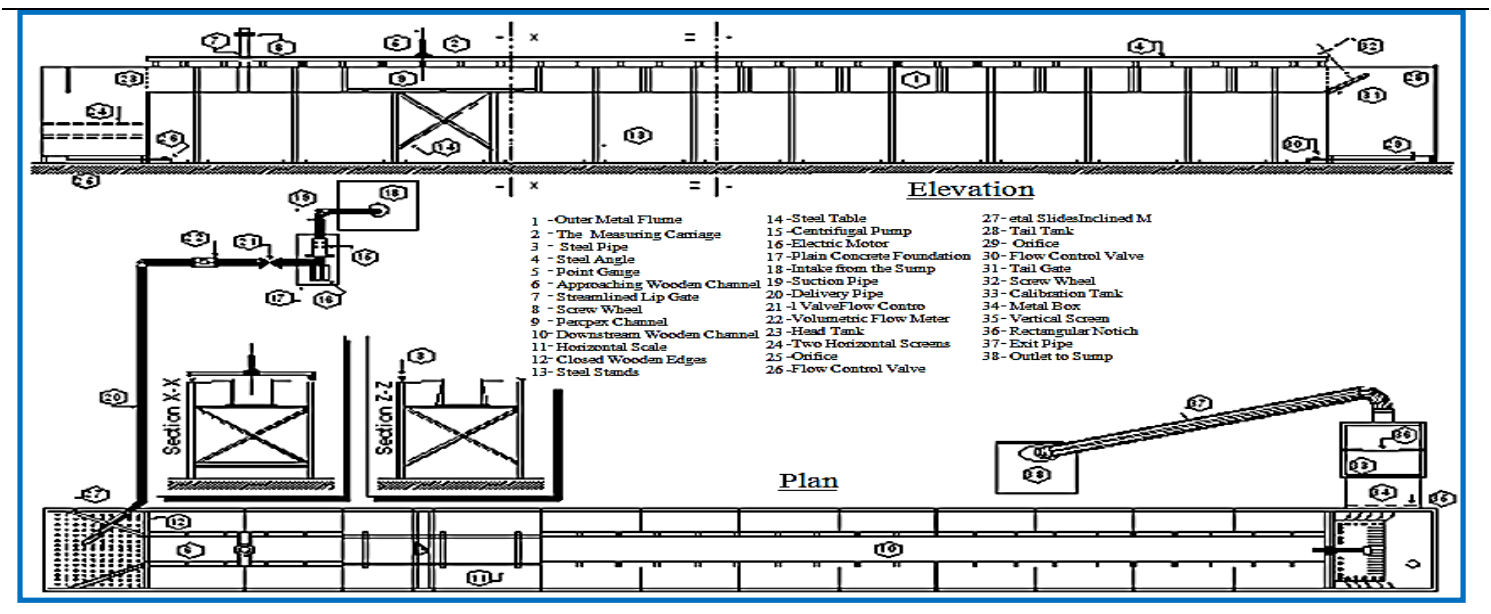

Fig. (1.a): Experimental apparatus and circulating system.

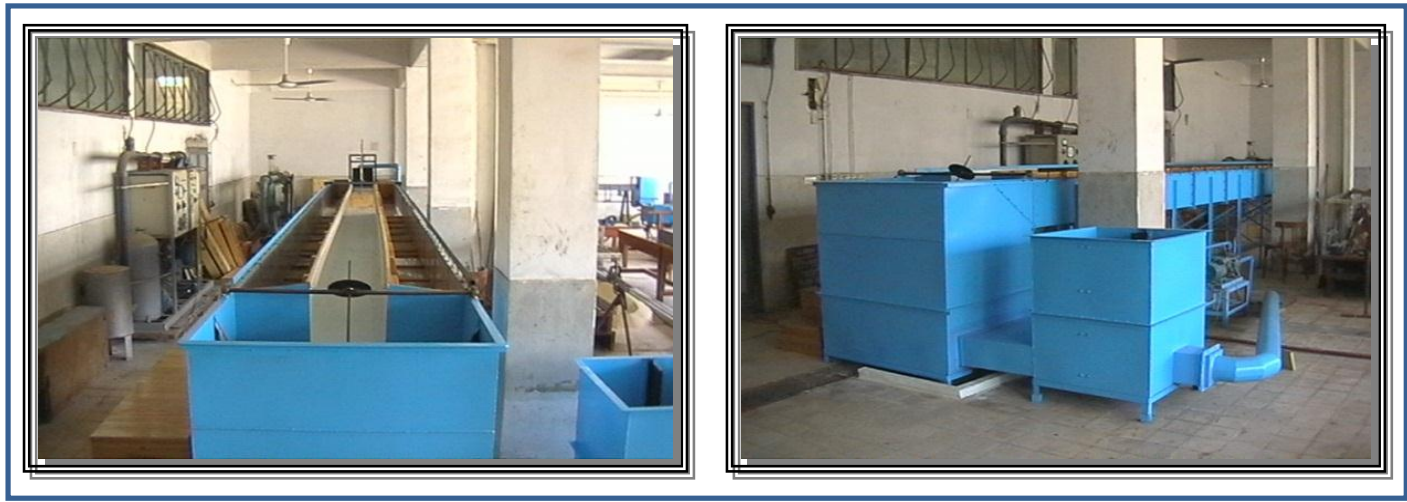

Fig. (1.b): The apparatus and its 'side view'.

Different four wooden models of accumulated sediments are used as shown in Fig. (2) and Table (1). A narrow wooden crested weir with crest width of 4 $\mathrm{cm}$ and $15 \mathrm{~cm}$ in height with a base width of $11.5 \mathrm{~cm}$ is chosen for experimental tests. The general layout of these models is illustrated in Fig. (3).

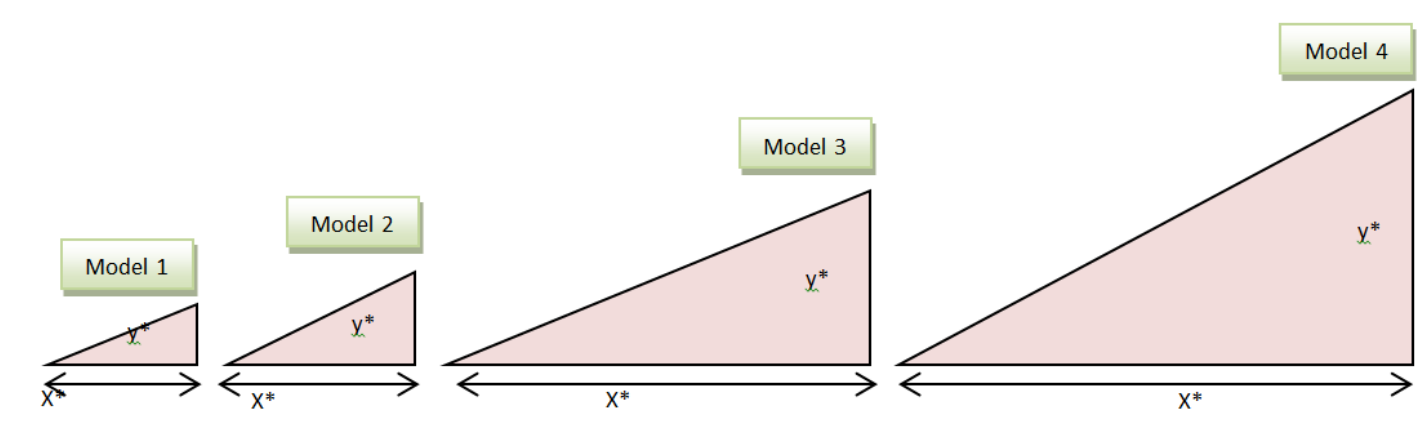

Fig. (2): Sketch of selected wooden models. 
Table (1): Dimensions of selected models.

\begin{tabular}{|c|c|c|}
\hline Model No. & $\mathrm{X}^{*}(\mathrm{~cm})$ & $\mathrm{y}^{*}(\mathrm{~cm})$ \\
\hline 1 & 5 & 2 \\
\hline 2 & 7 & 3 \\
\hline 3 & 14 & 7 \\
\hline 4 & 17 & 10 \\
\hline
\end{tabular}

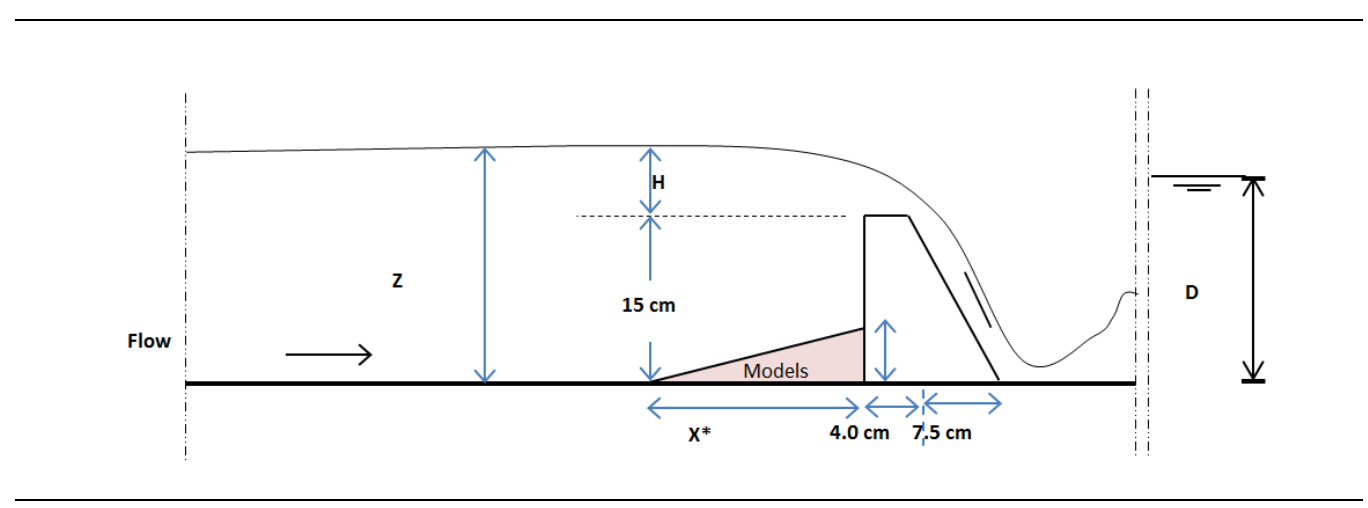

Fig (3): Layout of models

where:

$\mathrm{D}=$ downstream normal water depth;

$\mathrm{H}=$ head of water above weir crest; and

$\mathrm{Z}=$ maximum height of back water curve.

After adjustment of the models, different four discharges of 8 lit. /sec., 10 lit. /sec., 13 lit. /sec. and 15 lit. /sec. are used. The downstream normal water depth (D) and the corresponding normal water velocity are measured, Table (2).

Table (2): Used discharges and the corresponding measured D.S. depths and velocities.

\begin{tabular}{|c|c|c|}
\hline $\begin{array}{c}\text { Discharge } \\
\text { Q lit. /sec. }\end{array}$ & $\begin{array}{c}\text { D.S. normal water } \\
\text { depth }(\mathbf{D}) \mathrm{cm}\end{array}$ & $\begin{array}{c}\text { corresponding water velocity }(\mathrm{V}) \\
\mathrm{m} / \mathrm{sec} .\end{array}$ \\
\hline $\mathbf{8 . 0}$ & 20.00 & 0.10 \\
$\mathbf{1 0 . 0}$ & 20.80 & 0.12 \\
$\mathbf{1 3 . 0}$ & 21.70 & 0.15 \\
$\mathbf{1 5 . 0}$ & 22.80 & 0.16 \\
\hline
\end{tabular}

For each discharge, the maximum height of back water curve $(\mathrm{Z})$ and the head over weir crest $(\mathrm{H})$ are measured, then, the discharge coefficient $(\mathrm{Cd})$ is calculated from the following equation:

$Q=\frac{2}{3} C d B \sqrt{2 g} H^{\frac{3}{2}}$

where;

$\mathrm{Q}=$ discharge;

$\mathrm{Cd}=$ discharge coefficient;

$\mathrm{B}=$ weir width (equals $40 \mathrm{~cm}=$ channel

width for all runs);

$\mathrm{g}$ = gravitational acceleration; and

$\mathrm{H}=$ head over weir crest.
The experimental runs are repeated again with each of accumulated sediments models with the different four discharges.

\section{Results and analysis}

The first part of analysis concerns with the effect of selected different used models of accumulated sediments on the head of water over weir crest $(\mathrm{H})$ and the corresponding discharge coefficient $(\mathrm{Cd})$. The second one of analysis exhibits the effect of the used models on the maximum height of back water curve. These analyses are important to determine the situation of removing sediments. 
- Head over Weir Crest (H) and Discharge Coefficient $(C d)$

The effect of accumulated sediments upstream weir on the head over weir crest $(\mathrm{H})$ and the discharge coefficient $(\mathrm{Cd})$ using the selected four discharges of 8 lit. /sec.,
10 lit. /sec., 13 lit. /sec. and 15 lit. /sec. respectively is illustrated in Figs. (4) Through (7).

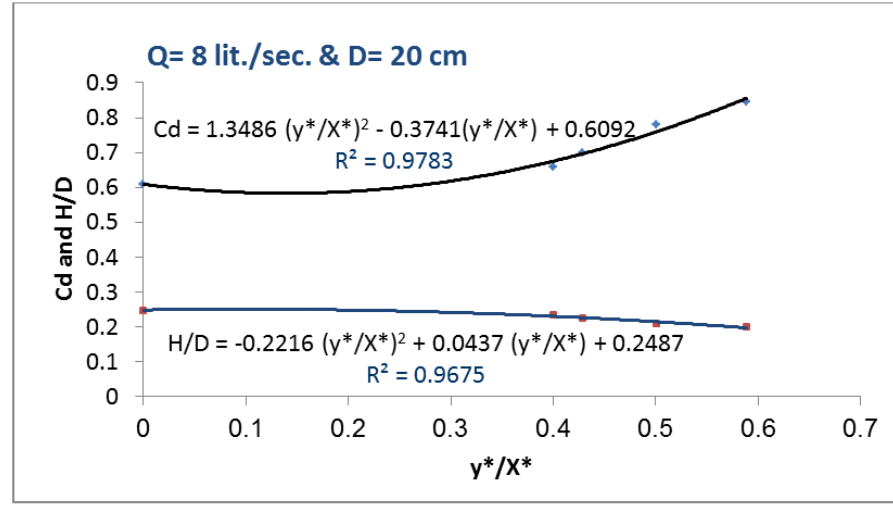

Fig. (4): Effect of accumulated sediment size ratio on Cd and (H/D) for $Q$ $=8.0$ lit. $/ \mathrm{sec}$.

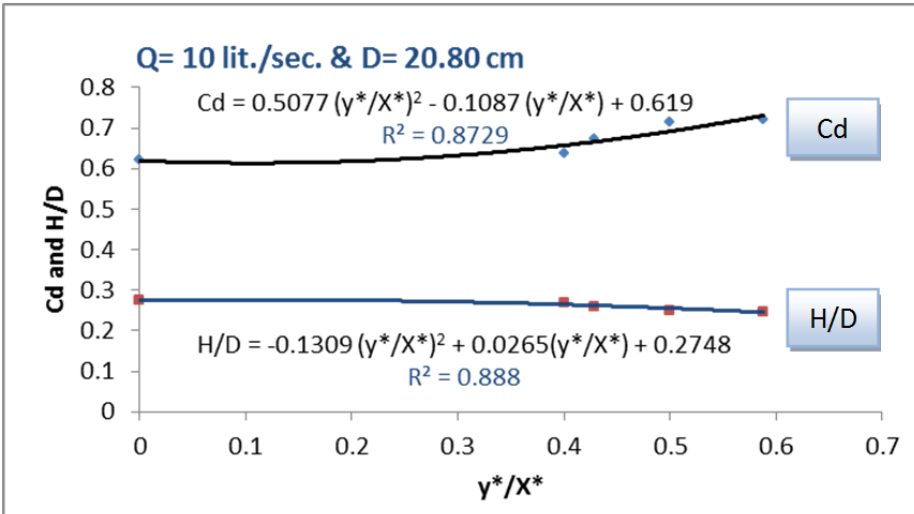

Fig. (5): Effect of accumulated sediment size ratio on $C d$ and (H/D) for $Q$ $=10$ lit. $/ \mathrm{sec}$.

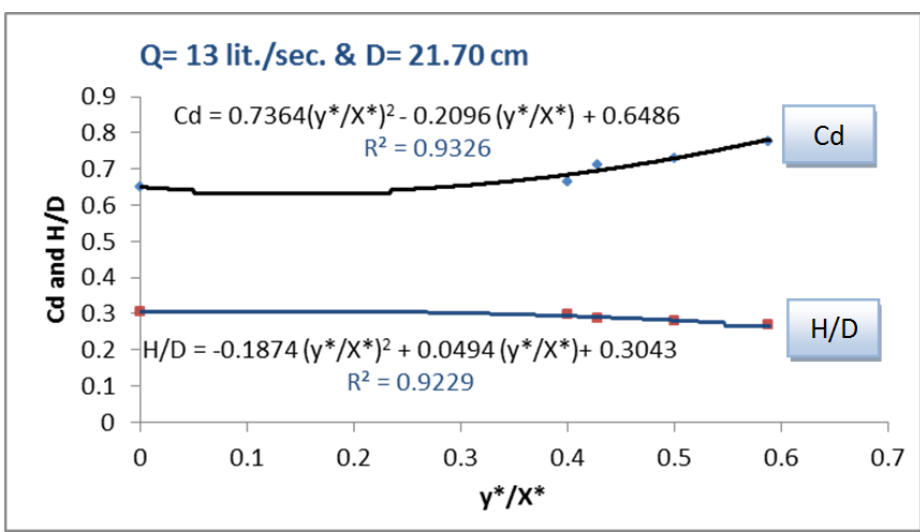

Fig. (6): Effect of accumulated sediment size ratio on $C d$ and (H/D) for $Q$ $=13$ lit. $/$ sec. 


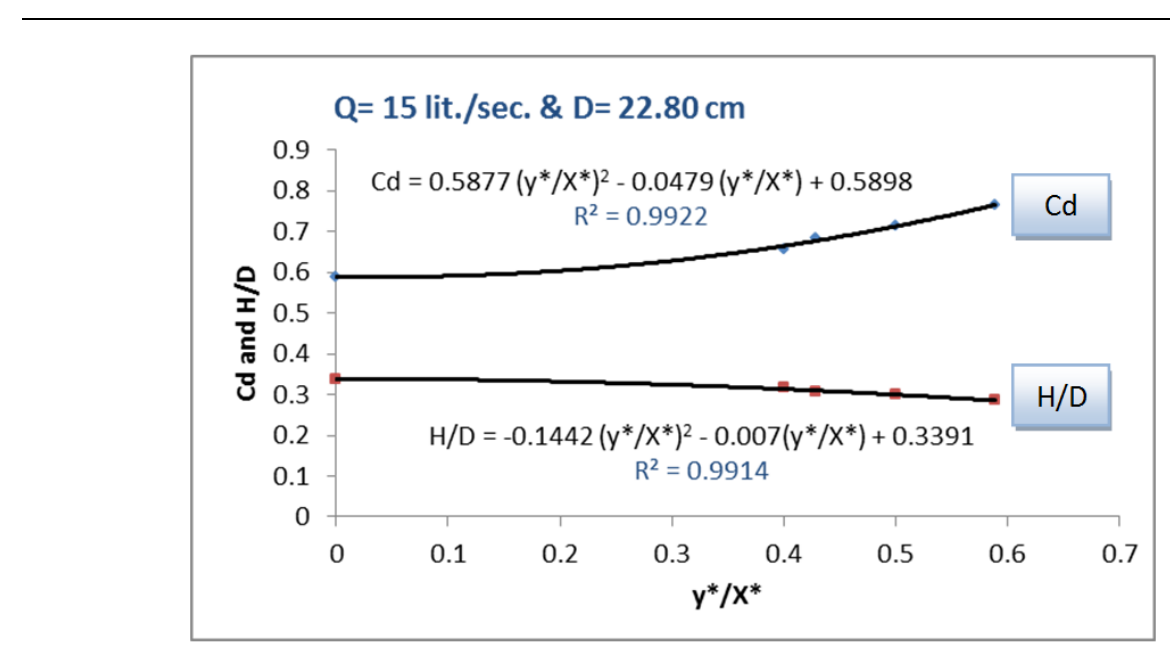

Fig. (7): Effect of accumulated sediment size ratio on $\mathrm{Cd}$ and (H/D) for $Q=15$ lit. /sec.

From analysis of the abovementioned figures, it is illustrated that with the increasing of the accumulated sediments the head above weir crest $(\mathrm{H})$ decreases gradually and the corresponding values of discharge coefficient $(\mathrm{Cd})$ increase by polynomial equations of the second degree for all discharges.
To associate all affecting parameters with each other's, dimension analysis is carried out. Equations (2) through (9) presents the relation between sediment size ratio $\left(y^{*} / X^{*}\right)$ and both of the ratio of head over weir crest with D.S. normal water depth $(\mathrm{H} / \mathrm{D})$ and the corresponding discharge coefficient $(\mathrm{Cd})$.

at $Q=8.0$ lit. $/ \mathrm{sec}$.

$$
\begin{aligned}
& \frac{H}{D}=-0.2216\left(\frac{y^{*}}{X^{*}}\right)^{2}+0.0437\left(\frac{y^{*}}{X^{*}}\right)+0.2487 \quad\left(\mathrm{R}^{2}=0.9675\right) \\
& C d=+1.3486\left(\frac{y^{*}}{X^{*}}\right)^{2}-0.3741\left(\frac{y^{*}}{X^{*}}\right)+0.6092 \quad\left(\mathrm{R}^{2}=0.9783\right)
\end{aligned}
$$

- at $\mathrm{Q}=\mathbf{1 0 . 0}$ lit. $/ \mathrm{sec}$.

$$
\begin{aligned}
& \frac{H}{D}=-0.1309\left(\frac{y^{*}}{X^{*}}\right)^{2}+0.0265\left(\frac{y^{*}}{X^{*}}\right)+0.2748 \quad\left(\mathrm{R}^{2}=0.8880\right) \\
& C d=+0.5077\left(\frac{y^{*}}{X^{*}}\right)^{2}-0.1087\left(\frac{y^{*}}{X^{*}}\right)+0.6190 \quad\left(\mathrm{R}^{2}=0.8729\right)
\end{aligned}
$$

- at $Q=13.0$ lit. /sec.

$$
\begin{aligned}
& \frac{H}{D}=-0.1874\left(\frac{y^{*}}{X^{*}}\right)^{2}+0.0494\left(\frac{y^{*}}{X^{*}}\right)+0.3043 \quad\left(\mathrm{R}^{2}=0.9229\right) \\
& C d=+0.7364\left(\frac{y^{*}}{X^{*}}\right)^{2}-0.2096\left(\frac{y^{*}}{X^{*}}\right)+0.6480 \quad\left(\mathrm{R}^{2}=0.9326\right)
\end{aligned}
$$


- at $Q=15.0$ lit. $/$ sec.

$$
\begin{aligned}
& \frac{H}{D}=-0.1442\left(\frac{y^{*}}{X^{*}}\right)^{2}+0.0070\left(\frac{y^{*}}{X^{*}}\right)+0.3391 \quad\left(\mathrm{R}^{2}=0.9914\right) \\
& C d=+0.5877\left(\frac{y^{*}}{X^{*}}\right)^{2}-0.0479\left(\frac{y^{*}}{X^{*}}\right)+0.589
\end{aligned}
$$

From the analysis of results, compared with the case of no sediments, it is observed that with the increasing of the accumulated sediments, the head over weir crest $(\mathrm{H})$ decreases by about $16 \%$ and consequently, the discharge coefficient $(\mathrm{Cd})$ of weir increases by about $38 \%$ as average percentage for all discharges. So, it is recommend removing the accumulated sediments upstream weirs to raise the heading up and water level.

\section{- Maximum rise of Back Water Curve}

The effect of accumulated sediments upstream weir is obviously appeared on the head over crest for all discharges as mentioned before, and consequently, it is important to determine exactly this effect on the maximum water height upstream weir of the back water curve $(Z)$ for all used selected models.

Figs. (8) through (13) show the change of maximum height of back water curve divided on D.S. normal water depth (Z/D) with the variation of accumulated sediments size ratio $\left(\mathrm{y}^{*} / \mathrm{X}^{*}\right)$ for all discharges respectively.

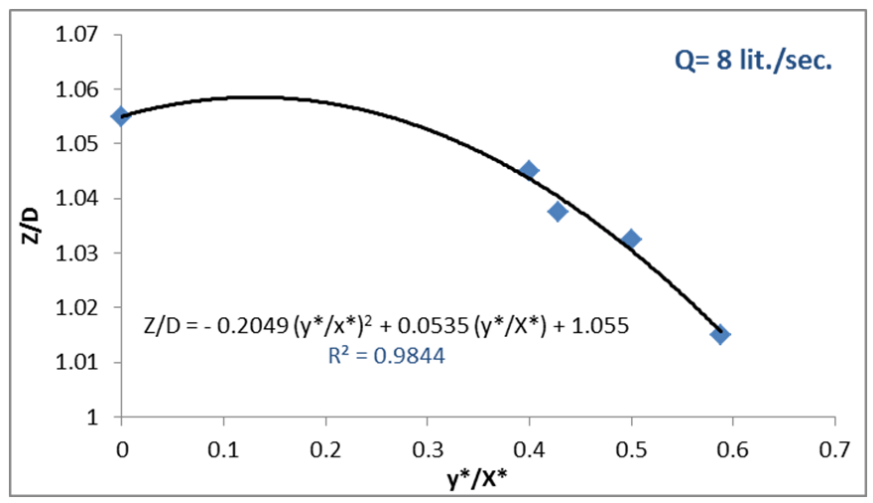

Fig. (8): Effect of accumulated sediments size ratio on $(Z / D)$ for $Q=8$ lit. $/$ sec.

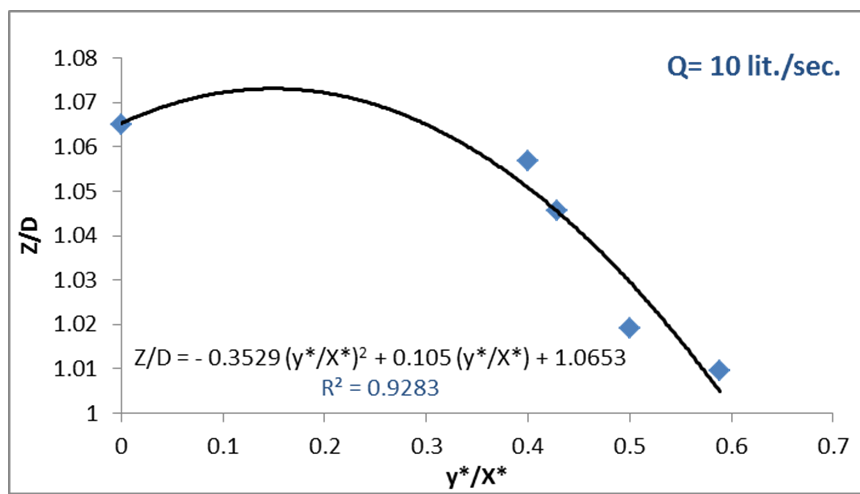

Fig. (9): Effect of accumulated sediments size ratio on (Z/D) for $Q=10$ lit. / sec. 


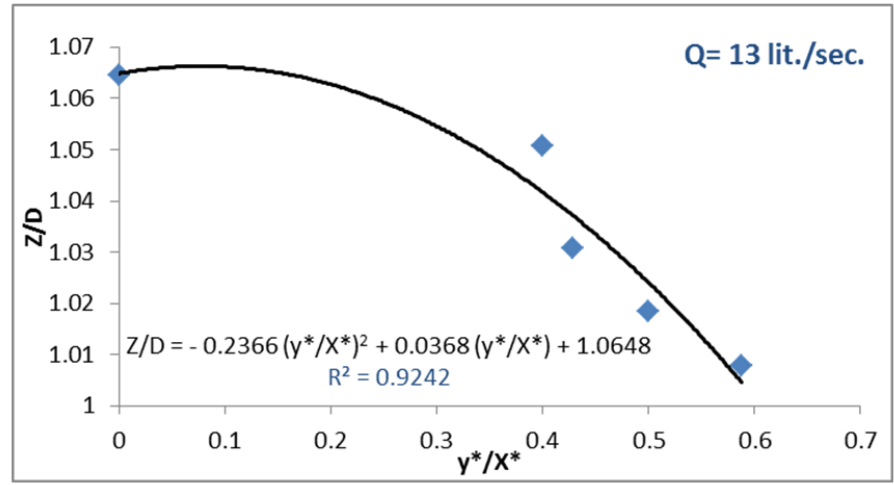

Fig. (10): Effect of accumulated sediments size ratio on (Z/D) for $Q=13$ lit. / sec.

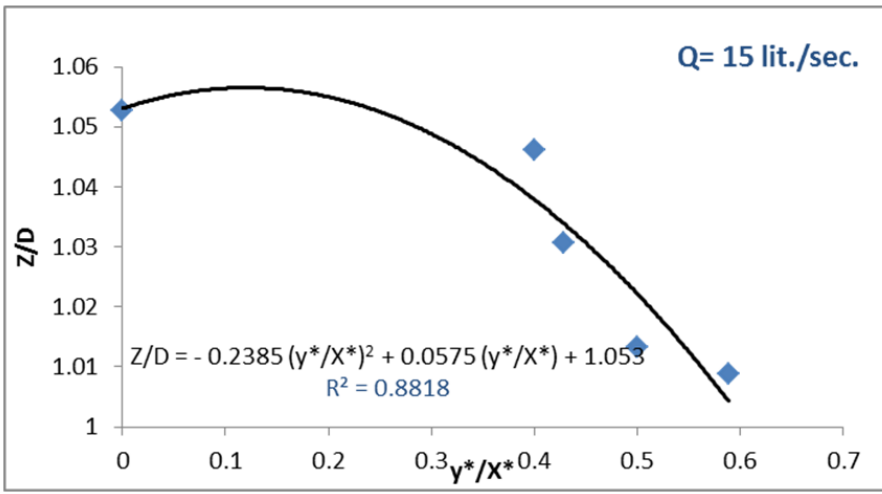

Fig. (11): Effect of accumulated sediments size ratio on (Z/D) for $Q=15$ lit. / sec.

The effect of accumulated sediments size ratio $\left(\mathrm{y}^{*} / \mathrm{X}^{*}\right)$ on the ratio between maximum back water height and D.S. normal depth ratio (Z/D) for all discharges, could be appeared in Equations (10) through (13).

- at $Q=8.0$ lit. /sec.

$$
\frac{Z}{D}=-0.2049\left(\frac{y^{*}}{X^{*}}\right)^{2}+0.0535\left(\frac{y^{*}}{X^{*}}\right)+1.055 \quad\left(\mathrm{R}^{2}=0.9844\right)
$$

\section{- at $\mathbf{Q}=\mathbf{1 0 . 0}$ lit. /sec.}

$$
\frac{Z}{D}=-0.3529\left(\frac{y^{*}}{X^{*}}\right)^{2}+0.105\left(\frac{y^{*}}{X^{*}}\right)+1.0653 \quad\left(\mathrm{R}^{2}=0.9283\right)
$$

\section{- at $\mathbf{Q}=\mathbf{1 3 . 0}$ lit. /sec.}

$$
\frac{Z}{D}=-0.2366\left(\frac{y^{*}}{X^{*}}\right)^{2}+0.0368\left(\frac{y^{*}}{X^{*}}\right)+1.0648 \quad\left(\mathrm{R}^{2}=0.9242\right)
$$


- at $Q=15.0$ lit. /sec.

$$
\frac{Z}{D}=-0.2385\left(\frac{y^{*}}{X^{*}}\right)^{2}+0.0575\left(\frac{y^{*}}{X^{*}}\right)+1.055 \quad\left(\mathrm{R}^{2}=0.8818\right)
$$

The maximum height of back water curve upstream weir (Z) decreases gradually with the increasing of accumulated sediments by about $5.3 \%$ as average percentage for all range of used discharges. For this reasons and analysis it is recommended to eliminate all of accumulated sediments upstream Fayoum type weirs.

Figs. (12) through Fig. (15) illustrate the variation in back water curve at discharges of 8 lit. /sec., 10 lit. /sec., 13 lit. /sec. and 15 lit. /sec. for all ranges of $\left(\mathrm{y}^{*} / \mathrm{X}^{*}\right)$.

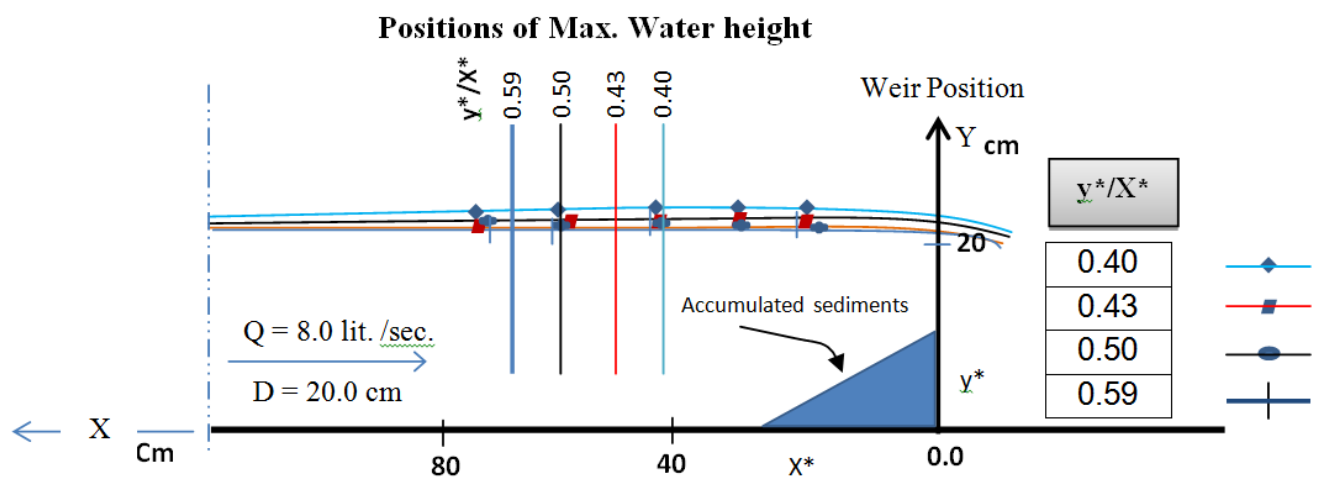

Fig. (12): Back water curve profiles for all accumulated sediment models at $Q=8$ lit. $/ \mathrm{sec}$.

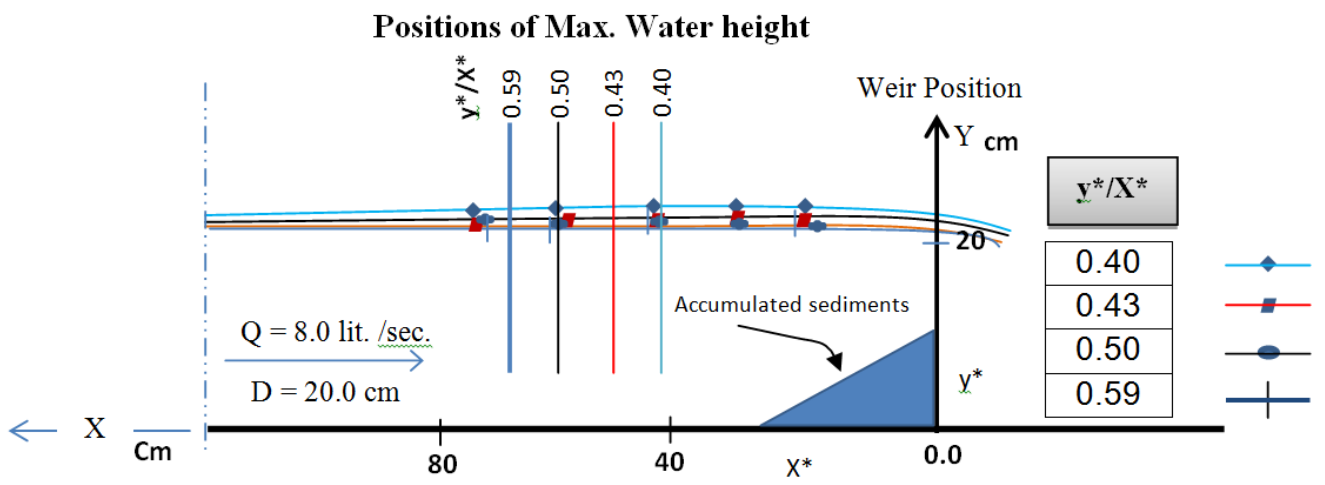

Fig. (13): Back water curve profiles for all accumulated sediment models at $Q=10$ lit. $/ \mathrm{sec}$. 


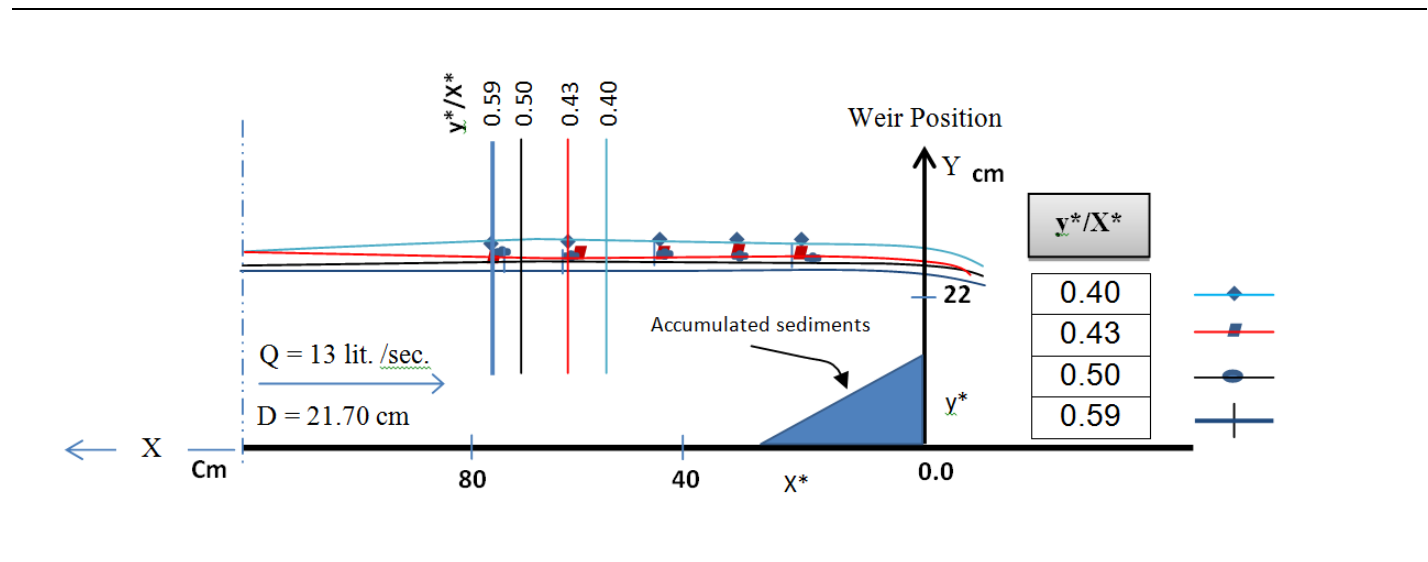

Fig. (14): Back water curve profiles for all accumulated sediment models at $Q=13$ lit. $/$ sec.

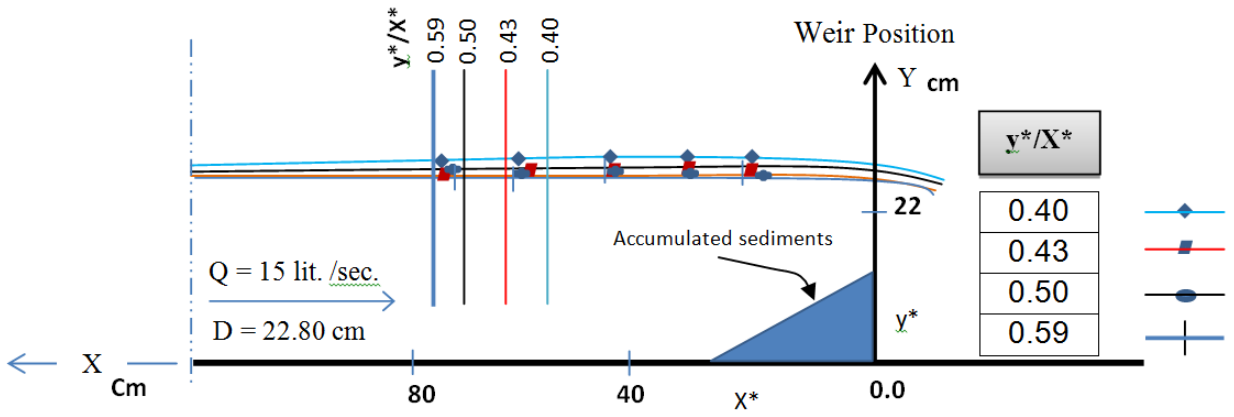

Fig. (15): Back water curve profiles for all accumulated sediment models at $Q=15$ lit. $/ \mathrm{sec}$.

It is illustrated from the abovementioned figures that the distance of maximum points for the back water curve from weir changes with the variation of accumulated sediments. With the increasing of accumulated sediments, the distance of maximum point of back water curve from the weir increases, the approaching water depths upstream weir decrease and the corresponding velocities increase.

\section{Conclusions}

In this research, experimental runs were carried out to find out the effect of accumulated sediments on narrow crested weir (Fayoum type) characteristics and also the variation in back water curve upstream it. This experimental work was carried out using four wooden different sizes of accumulated sediments ( $\mathrm{y}^{*}$ and $\mathrm{X}^{*}$ ) under various four discharges of 8 lit. /sec., 10 lit. /sec., 13 lit. /sec. and 15 lit. /sec. It is found from this study that the accumulated sediments upstream weir clearly affects the head over it $(\mathrm{H})$ and the back water profile. It was noticed that with the increasing of accumulated sediments, the head over weir crest $(\mathrm{H})$ decreases by about $16 \%$ and consequently, the discharge coefficient of weir increases by about $38 \%$. The maximum height of back water curve upstream weir $(Z)$ decreases gradually with the increasing of accumulated sediments by about $5.3 \%$. For this reasons and analysis it is recommended to eliminate all of accumulated sediments upstream Fayoum type weirs.

\section{Acknowledgments}

Grateful thanks for all staff of Irrigation and Hydraulics Department Faculty of Engineering - Mansoura University 


\section{References}

[1]. Abdel Halim, N. A., Sherif, M. M., and El-Zaher, A. S. (1991). "On the Fayoum Weirs with Orifices ", J. of Eng. and Applied Scie., Faculty of Eng., Cairo Univ., Egypt, Vol. 38, No. 5, pp. 893-904.

[2]. Alhamid, A. A., Negm, A. M. and AlBrahim, A. M. (1997). "Discharge Equation for Proposed Self-Cleaning Device" J. of King Saud Univ., Eng. Scie., Riyadh, Saudi Arabia, Vol. 9, No.1, pp. 13-24.

[3]. Alhamid, A. A. (1999). "Analysis and Formulation of Flow through Combined V-Nochgate Device" J. of Hyd. Res., Vol. 37, No. 5, pp. 697705.

[4]. Ansar, M. (2001). "Discussion of Simultaneous Flow over and Under a Gate" J. of Irrig. \& Drain. Eng., pp. 325-328.

[5]. Bos, M. G., Clemmens, A. J. and Replogle, J. A. (1986). "Design of Long-Throated Structures for Flow Measurement", Irrig. and Drain. Syst.1, pp. 75-92.

[6]. Ferro, V. (2000). "Simultaneous Flow over and Under a Gate", J. of Irrig.\& Drain. Eng., Vol. 126, No. 3, pp.190193.

[7]. Ggğüş, M., Defne, Z. and Ozkandamie V. (2006). "BroadCrested Weirs with Rectangular Compound Cross Sections", J. of Irrig. \& Drain., Vol. 132(3), pp. 272280.

[8]. Gonzalez, C.A., and Chanson, H. (2007). "Experimental Measurements of Velocity and Pressure Distribution on a Large Broad-Crested Weir", Flow Measurement and
Instrumentation, Vol.18, pp. 3-4 and pp. 107-113.

[9]. Hager, W. H. and Schwalt, M. (1994). "Broad-Crested Weir", J. of Irrig. \& Drain. Eng., Vol. 120, No. 1, pp. 1326.

[10]. Mohamed, H. I. (2005). "Discharge Measurement in Trapezoidal Lined Canals Utilizing Horizontal and Vertical Transitions", 9th Int. Water Tech. Conf. (IWTC9), Sharm ElSheikh, Egypt.

[11]. Negm, A. M., Abdel-Aal, G. M., Matin, A. M. and Alhamid, A. A. (1997). "Discharge Equation for Free and Submerged Flow through Combined Weir" Proc. Of Al-Azhar Eng.3rd Int. Conf., Faculty of Eng., Al-Azhar Univ., Cairo, Egypt, pp. 456470

[12]. Negm, A. M., Al-Brahim, A. M., Alhamid, A. A. (2002). "CombinedFree Flow over Weirs and below Gates", J. of Hyd. Res., Vol. 40, No. 3, pp.359-365.

[13]. Samani, J. M. V. and Mazaheri M. (2009). "Combined Flow over Weir and under Gate" J. of Hyd. Eng., Vol. 35, No. 3, pp. 224-227.

[14]. Sargison, J. E. and Percy, A. (2009). "Hydraulics of Broad-Crested Weirs with Varying Side Slopes", J. of Irrig. \& Drain., Vol. 135, No. 1, pp. 115118.

[15]. Yeh, K., Sam S., Chen, H., Liao, C., Jia, V. and Zhang, Y. (2010). "Numerical Simulation of Sediment Transport and Morphological Change of Upstream and Downstream Reach of Chi-Chi Weir", Numerical Simulations - Examples and Applications in Computational Fluid Dynamics, Prof. Lutz Angermann (Ed.), ISBN: 978-953-307-153-4, In Tech, China. 